\title{
PUBLIKATSIOONE
}

\section{SELGITUSEKS BETTI ALVERI VIIMASELE SÕNAVÕTULE}

Möödunud aasta lõpul üht ja teist Betti Alveri luulevalimiku „Omajuur” jaoks üle kontrollides puutus tema viimase eluajal koostatud luuletuskogu „Üle aegade Assamalla" mustandmaterjalide hulgas silma keskmise suurusega $(16 \times 22,5 \mathrm{~cm})$ kollakas ümbrik märksõnaga „Luule” ja daatumiga „1988 aug.” (KM EKLA, f 315, m 78). Ümbrikus oli kimbuke märkmeid erinevat mõõtu paberilehtedel ja -lipikutel, osalt perioodiliste väljaannete tellimislehtedel ühtekokku 46 sedelit. Kiirustava käega üles tähendatud märkmed rabasid avameelsusega: Betti Alver, kes avalikkuse ees harva soostus oma elu ja loomingut kommenteerima, valib hoolega sõnu ka kirjavahetustes ja päevikutes. ${ }^{1}$ Pikemaid kirjeldusi, jälgi loometööst, eneseeritlusi, pihtimusi on tulnud otsida tikutulega. Ja nüüd siin sellised valusad read: „Ma ei tunne ennast tänini. Võin ainult aimata, miks ma nii või teisiti käitu(si)n [---] miks jooksin rõõmu eest ära? (Ida tulek) [---] ikka tundsin end süüdlasena [---] ma ei uskunud (reaalsust), uskusin imet."

Märksõnad päris algus, sellega ehk lõpetada osutasid sellele, et tegemist on kas sõnavõtu või kirjutise kavandiga. Esialgu arvasin, et ülestähendused on seotud „Üle aegade Assamalla” valmimisega, ent siis jõudsin märkmete juurde 8. augustist 1988: „Oleks armetu ja koomiline, kui mina, ühe nii väikese rahva tundmatu ... suurele maailmale ja tema .... loojatele midagi suurt, uut luule kohta öelda." Tekst pidi olema adresseeritud lugejale või kuulajale väljaspool Eestit.

Märkmed on hoolikalt dateeritud, hiljem rühmitatud, tähistatud on loo algus ja lõpp ning arvatav keskne teema „Murelaulikud Eestis”. „Luule algab sealt, kus elava inimhääle saab valu," kirjutab Betti Alver. Ta peab meie rahvaluule krooniks murelaule, sest „[v]õib-olla ainult murelaulik teab õieti, mis on rõõ $[\mathrm{m}]$ ja inimlik õnn", ning asetab enesegi Eesti mureluule konteksti. Teksti adresseerimine suurele maailmale ja taoline üldistus tekitasid küsimuse selle loomise ajendist, eesmärgist. Mingil juhul ei saanud see olla tema viimase luuletuskogu selgituseks.

Ei ole saladus, et Betti Alver esitati Nobeli 1988. aasta kirjandusauhinna kandidaadiks. Sellest on juttu Karl Muru Alveri-monograafiaski (Muru 2003: 245). Tundus tõenäoline, et tegemist on võimaliku Nobeli-kõne kavandiga. Selgust selles küsimuses lootsin saada Betti Alveri arhiivist, tema kirjavahetustest, eelkõige aga tema päevikutest, kus ta oma eluoluliste sündmuste ülestähendamisel on ajuti olnud vägagi täpne.

Esimese teate Nobeli preemia kohta leidsin 1. novembril 1987 päevikusse tehtud sissekandest: „Meeletu kiri A.-M. Hallikult (Nobeli pr.)” (KM

${ }^{1}$ Alveri päevikute kohta vt Metste 2006. 
EKLA, f 315, m 87: 1, 1 181p). Ka Anne-Malle Halliku kiri leidub Betti Alveri arhiivis. Sellest selgub, et Kanadas asuv Eesti Tõlkefond on esitanud Betti Alveri Nobeli kirjandusauhinna kandidaadiks, samuti tahaks välja anda tema valikkogu ja sooviks selleks Alveri nõusolekut (KM EKLA, f 315, m 11: 7, $17 / 25 p)$.

Betti Alveri kandidatuur oli väliseesti ringkondades kõne all olnud varemgi: 8. novembril 1987 koos Enn Lillemetsaga Alverile külla tulnud Jaan Toomingale „öelnud kunagi Peeter Puide Rootsis, Nob. pr. kandidaatideks B.A. ja Uku Masing" (KM EKLA, f 315, m 87: 1, 1 181p). 10. novembril kirjutas Betti Alver Anne-Malle Hallikule vastuseks:

Kuigi mulle sama asja ka teisalt on räägitud, tundub see ikkagi natuke muinasjutu moodi.

Kui aga tõlkefondil - millest kirjutate - on kavatsus mu luulevalimikku inglise keeles välja anda, siis olen sellega põhimõtteliselt muidugi nõus - juhul kui leiduks vastav tõlkija. Kerge see ülesanne teadagi ei ole. (KM EKLA, f 315, m 5: 2, 1 135; ärakiri)

1987. aasta sügisel olid Betti Alveril pingelised ajad: käsil oli neljaköiteliseks kavandatud kogutud teoste ettevalmistamine. Esimese ja teise köite käsikiri - esimeses lüürika, teises poeemid ja ballaadid - pidi valmima 1. detsembriks 1987, järgmiste köidete käsikirjad maiks 1988. (Muru 2003: 234) 27. oktoobril oli Betti Alver palunud kirjastuselt ajapikendust kuni 1. märtsini 1988. Karl Muru resümeerib: „Kavandatud tempo oli eaka ja oma töö suhtes väga nõudliku Betti Alveri jaoks paratamatult liiga kiire. Lihtne lahendustee luuletajat ei ahvatlenud." (Muru 2003: 235)

Aega röövis nii igapäevaelu korraldamine kui ka lähenev sünnipäev. Päevikusissekanne 23. novembril 1987 annab teada: „Külalised, lilled, kingitused, üllatused...." 25. novembril on saabunud kiri Talvi Laevalt: „Koos ameerika poeediga tõlkivat nad terve „Tolmu ja tule” ja teisi luuletusi ingl. keelde (90 luuletust kevadeks). [---] Tahab tulla varakevadel minu juurde." (KM EKLA, f 315, m 87: 1, 1 183) 27. novembril saabunud kiri Eesti Raamatust aga tõi rahustava teate, et luuleraamatu tähtaega pikendatigi 1 . märtsini.

Esimese kirja oli Talvi Laev New Yorgist Betti Alverile läkitanud juba 8. septembril 1987, andes teada, et aitab tõlkida tema luulet omavanusel ameeriklannal, kes olevat Betti Alveris leidnud hingesugulase, kuid ise eesti keelt ei valda. 11. detsembril on Talvi Laev jälle kirjutanud: suur osa tõlketööst olevat juba tehtud, nüüd on vaja Alveri kirjalikku luba tõlgete avaldamiseks, kuigi kirjastajat veel ei ole (KM EKLA, f 315, m 17: 7, 1 1/1-3/6).

Vähesed detsembrikuised sissekanded Alveri päevikus kõnelevad enamasti argiaskeldustest, kirjamustandite kaustik teatab arvukate uusaastatervituste postitamisest kuu lõpul ja 1988. aasta jaanuari algul. Suure intensiivsusega on ta tegelenud luulekogu käsikirjaga, on lükanud tagasi kaastööettepanekud Loomingule, vastu võtnud vaid üksikuid külalisi. 14. jaanuaril saabus kiri Kathryn Metsalt: „kirjutab BA ingl.keelsest luulekogust, mis ilmuvat Kanadas” (KM EKLA, m 87: 1, 1 185p). „See oleks igavene hea, sest tähendaks laie- 
mat lugejaskonda. Jne.," on Kathryn Mets rõõmustanud (KM EKLA, f 315, m 20: $12,127 / 67){ }^{2}$

Veebruari keskpaiku tahtis Betti Alverit külastada Helsingisse õppima asunud Talvi Laev. Ta oligi 17. veebruaril Eestis, Tallinnas, kuid Tartusse teda ei lubatud. 23. veebruaril jõudsid vahendajate kaudu Betti Alverini Talvi Laeva kiri ning saadetis, 44 luuletuse tõlked inglise keelde, selgus ka, et ameeriklannast tõlkija nimi on Gabriella Mirollo (KM EKLA, f 315, m 87: 1, 1 186p). 26. veebruaril 1988 kirjutas Betti Alver Talvi Laeva kirjadele vastuse: „Loomulikult ei ole mul midagi luulevalimiku avaldamise vastu inglise keeles. Muidugi eeldades, et tõlge on ikkagi nõutaval tasemel. Tõelise hinnangu andmiseks pole mu inglise keele oskus küllaldane. Ometi näib mulle, et tõlge on tehtud hoole ja süvenemisega. Loodetavasti ka talendiga." Alveri arvates oli 90 luuletust valimiku jaoks „vist enam kui piisav”, välja palus ta jätta luuletused „Vanapoisi pulmad” ja „Sina ütled: katoliiklikult kartes”, mis ta oli välja praakinud ka käsilolevast suurest luulekogust. Lisaks rõhutas ta, et ei ole huvitatud honorarist mitte mingisugusel kujul, ning rõõmustas, et valimikku on võetud ka luuletusi tema värskeimast, 1986. aastal ilmunud kogust „Korallid Emajões". (KM EKLA, f 315, m 2: 1, l 1/1; m 5: 2, l 140, 141)

Samal päeval on ta vastanud ka Anne-Malle Halliku kirjadele 30. detsembrist 1987 ja 19. veebruarist 1988. Viimasega oli Hallik edasi saatnud Eesti Tõlkefondi tutvustava bukleti, mis kõneleb järgmist: „Iga kirjaniku looming on tema rahva varandus. Iga tõlgitud teos on ühe rahva omapära ja vaimse rikkuse tutvustajaks teistele. Tõlgitud raamatute järele hinnatakse ka rahva küpsust ja suurust - suurust, mis vaevalt ühtub rahvamasside arvulise hulgaga. [---] iga tõlgitud raamat teenib otseselt meie vabadusvõitlust, juhtides maailma tähelepanu eesti rahvale - seega ka eesti rahva saatusele ja venelaste kestvale roimale Baltimaadel. [---] Ehitagem Eesti Tõlkefondiga sild tulevikku ja teiste rahvaste juurde! Ulatagem neile Marie Underi, Betti Alveri, Anton H. Tammsaare, August Gailiti, August Mälgu ja teiste loomingu paremik!"

Kanadast saabunud buklet, ilma ühegi selgituseta tõlkimise käigu kohta, oli Anne-Malle Hallikut tõsiselt pahandanud, ${ }^{3}$ ent Betti Alver palus teda raamatu pärast mitte muretseda: „Küllap ka see asi laheneb ja läheb oma rada nagu kõik siin maailmas" (KM EKLA, f 315, m 5: 2, 1 143p). Kirjavahetusest Talvi Laevaga on ta vaikinud.

Eesti Raamatulegi on Betti Alver kirjutanud 26. veebruaril 1988, paludes veel kord luuleraamatu tähtaega pikendada: „...luuletuste paigutamine või uhkemalt öeldes komponeerimine võtab rohkem aega kui esialgu arvasin” (KM EKLA, f 315, m 5: 2, l 143). Vastus kirjastusest on saabunud 4. märtsil: käsikirja tähtaega pikendati 16. maini 1988 (KM EKLA, f 315, m 87: 1, 1 187p; Muru 2003: 235). Tihe töö käsikirjaga jätkus. 31. märtsil, kui Mai Murdveele on ümberkirjutamiseks kaasa antud umbes 30 lehekülge käsikirja ja ka paberit, nenditakse päevikus: „sedapuhku vist lõpetus” (KM EKLA, f 315, m 87: 1, 1 188).

4. aprillil 1988 jõudsid Gabriella Mirollo ja Talvi Laeva tõlked Alverini ka Anne-Malle Halliku kaudu. Need oli Hallik saanud Doris Karevalt, oli need paljundanud ja pannud kiiresti teele nii Betti Alverile kui ka tõlkefondile

${ }^{2}$ Kirjavahetust Betti Alveriga alustas USA-s elanud Kathryn Mets 1969. aastal, kui tal oli käsil magistritöö kirjutamine Betti Alverist ja tema luulest (KM EKLA, f 315, m 20: 12, $11 / 1-1 / 2)$.

${ }^{3}$ Vt Anne-Malle Hallik Betti Alverile 19. II 1988 (KM EKLA, f 315, m 11: 7, 1 9/35). 
Kanadas (KM EKLA, f 315, m 151: 15, l 1/1). Järgmisel päeval kirjutatud vastuses tänas Betti Alver saadetise eest ja märkis, et täpselt samad tõlked olid tal juba olemas.

Suure pingega töötades 4 lõpetas Betti Alver mais „Assamalla” käsikirja ja saatis selle kuu viimasel päeval Karl Muruga Tallinna, kirjastusse (KM EKLA, f 315, m 87: 1, l 191p). Väsimus oli nii suur, et kui Karl Muru, kes oli varem saanud Betti Alverilt enda kätte kõik Heiti Talviku materjalid ja tõi nüüd Talviku vastilmunud luuleraamatu, ${ }^{5}$ ei saanud Alver temaga isiklikult kohtuda - raamatu võttis üle ukse vastu Renate Tamm. „Olen väsinud, haiglane," on ta märkinud päevikusse 5. juunil. Jaanipäeval käis Enn Lillemets ja tõi ära kümme eksemplari Betti Alveri jaoks ostetud Heiti Talviku luulekogu. Päevik fikseerib: „Enn Lillemetsal oli kaasas 19. juuni „Helsin[k]in Sanomat”, kus Nobeli pr. kandidaatide seas virolainen Betti Alver" (KM EKLA, f 315, m 87: 1, 1 192p-194).

Juuli algus on kulgenud harilikes askeldustes, ent siis, 19. juulil saabus kiri New Yorgist professor Mardi Valgemäelt ingliskeelse antoloogia asjus, kirjutatud 18. juunil 1988 (KM EKLA, f 315, m 31: 5, l 1/1). Lühikese enesetutvustuse järel on Mardi Valgemäe Betti Alverit informeerinud senisest tööst valikkogu koostamisel ja edaspidistest kavatsustest:

Teie valikkogusse tahaksin paigutada 80-100 luuletust - võib-olla koos eestikeelsete tekstidega. Momendil on olemas umbes 20 varem avaldet tõlget (E. Howard Harris, Ivar Ivask, W. K. Matthews, Felix Oinas / Willis Barnstone). Käsikirjas on umbes 120 (Jüri Kurman, Talvi Laev / Gabriella Mirollo, Merike Lepasaar-Beecher, Ilse Lehiste, Taimi Ene Moks). Tõlkeid on lubanud saata veel Urve Karuks, Tiina Kirss, Riina Tamm jt. Ameerika luuletaja William Collins on andnud omapoolse nõusoleku neid kõiki vajaduse korral siluda. Aastavahetusel tahame saata kimbu meie arust onnnestunud tõlkeid siinsetele kirjastustele, et kuulda nende arvamusi. Ärilisi kirjastusi on USA-s palju, nii suuri kui väikseid, ja 99,9 protsenti neist kindlasti ei tea midagi Eestist ega eestlastest, rääkimata siis veel eesti luulest. Siiski ilmus hiljuti siin kaks Jaan Kaplinski valikkogu, mis paneb meid lootusi hellitama. Ka ülikoolide kirjastused avaldavad vahetevahel baltiainelist materjali („Baltikum” on siin pisut tuntum termin kui „Eesti”), aga neile tuleb tavaliselt tublisti juurde maksta, sest selliste raamatute tiraazh on loomulikult väga piiratud, eriti siinseis mõotmeis, ega tasu ennast majanduslikult ära. Kust niisugune summa tuleks, seda ma praegu ei tea, aga Tõlkefond on siiani kandnud kõik tõlkekulud.

Nagu mainisin, oleksin huvitet teiepoolsetest mõtetest ja soovidest, näiteks luuletuste valiku osas või mis iganes. Enne kui astume ühendusse kirjastustega on ka vaja Teie põhimõttelist nõusolekut. Selleks piisab eestikeelsest (aga eraldi lehele paigutet) volituskirjast tõlkekogu avaldamiseks Eesti Tõlkefondi poolt.

Teile ilusat suve soovides ja parimate tervitustega [---]

Postskriptum annab teada, et lisatud on koopia Eesti PEN-klubi kirjast Nobeli komiteele: „See on aga usalduslik ja Nobelikomitee poolt avalikkusele teatamiseks keelatud." (KM EKLA, f 315, m 31: 5, 1 1/1)

${ }^{4}$ Vt ka Betti Alver Otto Luigale 7. VI 1988 (Lillemets, Metste 2007: 466).

${ }^{5}$ Talvik, Heiti. Luuletused. Koostanud Karl Muru. Tallinn: Eesti Raamat, 1988. 
Kõnealune koopia leidub endiselt Mardi Valgemäe kirja juures. Eesti PENklubi, kiri kannab Arved Viirlaiu allkirja, on Nobeli komitee poole pöördunud 10. jaanuaril 1988. Rõhutades seda, et ühe kirjaniku loomingu mõistmiseks tuleb tunda sotsiaalseid ja poliitilisi olusid, milles ta elas, on Betti Alver ja tema looming asetatud Eesti ajaloo konteksti: „Väikese rahva poeetilise häälena oli ta suure tundlikkuse ja kaastundega tunnistaja oma rahva rõõmudele, kaotustele ja katsumustele." Vastandatud on sõltumatuse kuldsed aastad kahe maailmasõja vahel ning Nõukogude okupatsiooni ja Teise maailmasõja põhjustatud katastroof; Betti Alveri noorusaeg, küpsemine Eesti väljapaistvaimaks luuletajaks ning tema kannatused Nõukogude okupatsiooni ajal: „Võõra ülemvõimu tagajärjed olid eriti karmid Betti Alverile. Oma abikaasa, poeedi Heiti Talviku surma järel poliitilise vangina vaikis see mõjukaim ja elavaim poeetiline hääl paljudeks aastateks."

Esile on toodud eksiilkirjanike roll eesti kirjanduse püsimajäämisel läbi kaose ja järgnenud terrori, mis sundis vaikima kolleegid kodumaal, ja nimetatud, et uus kevad puhkes kodumaa kirjanike jaoks alles Stalini surma järel. Betti Alveri looming on toodud esile kui särav eeskuju noortele eesti kirjanikele nii kodumaal kui ka eksiilis, tema talendi mõju on olnud ületamatu. Alveri nimetamine Nobeli kirjanduspreemia laureaadiks, ennekõike tema erakordse ande eest, sütitaks uut elu ja lootust paljude väikeste ja okupeeritud rahvaste kultuurilise ja keelelise suveräänsuse otsinguteks.

Betti Alveri vaimse vangistuse vastase trotsi sümbolina on kiri lõpetatud luuletusega „Tuulelapsed”, alates värssidest „Lennake läbi kõik mandrid! Las maha jääb / leplik legend” kuni luuletuse lõpuridadeni: „Seda raamatut uurige teie, mu sõbrad, / kui mina ei saa - / seal olevat hiiglaste hulgas ka üks peatükk / ESTON I A" (kirjas muidugi ingliskeelses tõlkes). PEN-klubi pöördumisele on lisatud, nagu ütleb märkus selle lõpus, mõned Betti Alveri luuletused tõlkes inglise ja saksa keelde.

Betti Alveri vastus Mardi Valgemäe kirjale on teele läinud 27. juulil ühes volitusega Eesti Tõlkefondile (KM EKLA, f 315, m 6: 1, 1 8-9; vt ka f 315, m 87: 1, 1 196p):

Austatud Mardi Valgemäe

Sain kätte Teie 18. juuni kirja koos lisandiga ja võtsin kõik endamisi teatavaks. Palun lubage mul sedapuhku oma tunnetest ja mõtetest vaikida. Millised need on, võite vist aimata.

Nüüd siis paar sõna kavatsetava luulevalimiku kohta. Mida sinna võtta, jäägu Teie kui toimetaja ja tõlkijate otsustada. Mingil määral oluliseks pean ehk järgmisi luuletusi:

Leib

Tähetund

Korallid Emajões

Võlg (Itepsile)

Udus

Masin (1 ja 2)

Vabaduse deemon (Jäägu teistele alandlik jaatus)

Sõnarine (on vist üldse tõlkimatu)

Tuulelapsed 
Kuid kordan veel, need luuletused pole üldse obligatoorsed - peaaegu kõik oleneb ju ikkagi tõlke õnnestumisest.

Meeleldi kuuleksin edaspidi, kas või kui soodsalt valimiku küsimus edeneb. Ometi poleks ma eriti valusalt pettunud ka vastupidise tulemuse puhul.

Teid ja teisi asjasse pühendatuid kõigest südamest tänades ja tervitades

Betti Alver

Kolme päeva pärast, 30. juulil 1988 on tehtud esimesed märkmed salapärases luuleümbrikus:

Võib-olla oleksin ma kogu maailmale ja oma kodumaale veidi paremat ja kergemat saatust soovinud. Kuid mis puutub minusse isiklikult - siis enesele vaevalt küll. [---] Ma ei ütleks, et mu isiklikud kogemused eriti julmad oleksid olnud. Kõik siin maailmas on ju suhteline. Julmaks võib mu kogemusi ainult nende kannatuste pärast nimetada, mis teistele mu kaasaegsetele osaks said. Ja kuna see vist on paraku üldinimlik ja veidi ebaeetilinegi - olid need mu elamused eriti rasked mulle isiklikult väga lähedaste inimeste traagilise saatuse ... puhul

Vist ei saa enam olla kahtlust, et leitud märkmed on ülestähendused võimaliku tänuavalduse tarbeks Nobeli kirjandusauhinna puhul. Tsiteeritud mõttearendus näib otseselt tõukuvat PEN-klubi pöördumisest.

Järgnevatel kuudel, nagu on näha kuupäevadest märkmete juures, on Betti Alver teemaga pidevalt tegelenud. Päevik seda ei nimeta, nagu ei maini ka tõlkimist ega auhinda. Ent ootamatusse kohta päevikus, augusti- ja septembrikuu sissekannete vahele jäänud kahest tühjast leheküljest vasakpoolsele (KM EKLA, f 315, m 87: 1, 1 199p) on märgitud:

1. nov. (pühap.) 1987 meeletu kiri Anne-Malle Hallikult (Nob. pr. kandidaat)

13. okt (neljap.) 1988 kuulsin õhtul raadiost, mis vaja

Hoogsalt, harilikust suurema käekirjaga kirjutatud teksti alla on sama hoogsalt visatud lõpmatuse sümbol $\infty$.

13. oktoobril 1988 tegi Rootsi Akadeemia teatavaks kirjandusauhinna 1988. aasta laureaadi. Selleks osutus egiptuse kirjanik Nagīb Maḥfūẓ (The Nobel Prize 1988). ${ }^{6}$

Järgmisel päeval, 14. oktoobril, nagu osutab Betti Alveri päevik, ilmus Sirbis ja Vasaras „Ivar Ivaski jutt, ms. B.A. ingl. keele luulevalimikust Ameerikas ja n. e." (KM EKLA, f 315, m 87: 1, l 201p). Kõne all on Ivaski asutatud Neustadti auhind, mida peetakse väärikaimaks tunnustuseks Nobeli kirjandusauhinna järel ja kutsutaksegi Ameerika Nobeliks (Kiin 2012). Ivaski usutleja Eerik Tedre küsimusele eestlastest auhinnakandidaatide olemasolu kohta on Ivaskil tulnud vastata eitavalt: „Aga mul oleks hea meel, kui esitataks näiteks Betti Alveri nimi. Enne seda on aga tarvis, et tema loomingu paremik oleks inglise või mõnesse teise rahvusvahelisse keelde tõlgitud. Praegu pro-

\footnotetext{
${ }^{6}$ Akadeemia põhjendas kõrgeima kirjandusauhinna andmist sellega, et Maḥfūẓ on oma „kõrgeväärtusliku loomingu kaudu, mis on niihästi teravapilguliselt tegelikkuselähedane kui ka sugestiivselt paljutähenduslik, kujundanud välja üldinimlikku tähendust omava araabiakeelse romaanikunsti” (Kasemaa 1988: 1717). Eesti keelde on Maḥfūzilt tõlgitud romaan „Tuhande öö ööd” (2004), tõlkija Kalle Kasemaa.
} 
fessor Mardi Valgemäe organiseeribki Alveri ingliskeelset valimikku mitmete tõlkijate osavõtul." (Ivask 1988)

18. oktoobril on saabunud Mardi Valgemäe vastus Betti Alveri kirjale 27. juulist, kirjutatud 5. septembril 1988: „Momendil ei ole midagi erilist teatada. Viimistleme toortõlkeid, et aastavahetuseks kirjastustele saatmiseks parajat kimpu kokku saada. Mõned Teie poolt soovitet luuletused on väga rasked tõlkida, aga teeme oma parima. Kirjutan paari kuu pärast jälle." (KM EKLA, f 31: 5, 1 2/5) Rohkem Mardi Valgemäe kirju Betti Alveri arhiivis ei ole. 2. juunil 1989 ilmus Sirbis ja Vasaras teade selle kohta, et Eesti Tõlkefond Torontos on juba aastaid organiseerinud Betti Alveri luule tõlkimist inglise keelde. Tõlkida tahetakse umbes paarsada luuletust, viimase paari aasta jooksul on tõlgitud $174,{ }^{7}$ tõlkijateks Jüri Kurman, Talvi Laev, Ilse Lehiste, Merike Lepasaar-Beecher, Elmar Maripuu, Gabrielle Mirollo, Taimi Ene Moks, Felix Oinas, Silvia Airik-Priuhka ja Riina Tamm ning valimiku toimetajaks Mardi Valgemäe. Märgitakse, et Betti Alver ise on tõlkijate tööga seotud, on osa luuletusi välja valinud ja tõlkimiseks soovitanud. Nimetatakse, et Eesti PENklubi on Betti Alveri esitanud kolmel korral Nobeli preemia kandidaadiks, kuid tema loomingust saadi tutvumiseks saata vaid Ants Orase saksakeelseid tõlkeid valimikust „Acht Estnische Dichter”, kus on avaldatud viisteist Betti Alveri luuletust, ja W. K. Matthewsi ingliskeelseid tõlkeid valimikust „Modern Estonian Poetry", kus Betti Alveri luuletusi on kümme. Ei jäeta mainimata, et üksikuid luuletusi on tõlgitud ka rootsi ja taani keelde. (Aleksius 1989) Mahukaid tõlkekogumikke vene keeles aga ei nimetata, ehkki autoriseeritud tõlgetena võiksid need olla Betti Alveri luule parimad näited võõrkeeles. ${ }^{8}$

Seda juttu Betti Alver aga enam ei näinud, nagu ei saanud lugeda ka „Üle aegade Assamalla" esimesi korrektuurpoognaid, mis saabusid juuni keskel. Igaviku uks sulgus tema järel 19. juunil 1989 koidu eel (vt ka Muru 2003: 246-248).

Suure tõlketöö tulemusena ilmus väike, sinakate kaantega, kaheksa luuletuse ingliskeelset tõlget sisaldav vihikuke „Selected Poems” (1989) nüüd juba Betti Alveri mälestuseks, leinaraamis teatega tema surmast esikaane siseküljel. ${ }^{9}$ Raamatu eessõnas avaldavad tõlkijaile tänulikud Arved Viirlaid ja Tõnu Parming, esimene Eesti PEN-klubi, teine Eesti Tõlkefondi president, lootust, et Alveri valitud luuletuste köide, mille ettevalmistamisel on kaasa löönud suur hulk inimesi üle terve ilma, ilmub lähemas tulevikus (Viirlaid, Parming 1989). Mardi Valgemäe teatel Karl Murule pandi käsikiri tõepoolest kokku, kuid „korduvatest katsetest hoolimata ei õnnestunud sellele leida turustamisriski trotsivat kirjastajat" (Muru 2003: 245).

Tol Betti Alveri viimasel sügisel Nobeli-kõne visandisse jõudnud mure teema on aga kajana kordunud mitmes pühadetervituses 1988/89. aasta vahetusel: „Mullu jõin murekarika, / tänavu jõin teise täie, / kolmat kannu kallatakse - / ja siiski-siiski-siiski [---] Uskugem rõõmu!”; „selles imelikus maailmas

${ }^{7}$ Ele Süvalepa andmeil pärineb Betti Alverilt üldse 260 luuletuse ringis (Süvalep 2005: $529)$.

${ }^{8} \mathrm{Vt}$ Звездный час. Стихи и поэмы. Москва. Советский писатель, 1973; $142 \mathrm{lk}$; Поэмы. Хлеб, Великая сушь, Босая нога. Таллинн: Ээсти раамат, 1976; $57 \mathrm{lk}$; Дети ветра. Стихотворения и поэмы.Москва: Художественная литература, 1979; 238 lk. Tõlkinud on Svetlan Semenenko ja Junna Moritz. Betti Alveri koostööd Semenenkoga peegeldab hästi nende kirjavahetus (vt Lillemets, Metste 2007: 286-325).

${ }^{9}$ Tegemist ei olnud niisiis Nobeli auhinna taotlemiseks välja antud raamatuga, nagu vahel arvatud. Vrd Põldmäe 2014: 538. 
on nii palju muret, häda ja õnnetust, et nagu ei olekski põhjust (eriti) rõõmus olla. Ja siiski - rõõmuta on võimatu elada!”; „me murelik ja ometi päris imeväärne maailm”; „kõigest hoolimata on see maailm siiski nii imepärane ja üllatav”; „kuigi maailm on üleni täis musta muret, pole rõomgi veel viimseni kadunud" (KM EKLA, f 315, m 6: 1, 1 19p-25p).

Kuna minu peamiseks allikaks olnud 1977.-1988. aasta päevikus lõpevad märkmed 29. oktoobriga 1988 ja kirjamustandite kaustikus on viimane kiri 18. jaanuarist 1989, vaatasin, lootuses leida loo kohta enam andmeid, läbi ka teised Betti Alveri viimaste aastate märkmikud-päevikud. Selgus, et need võivad olla vahetud märkmed. Need tõid sündmuste kohta veidi enam teateid, peamiselt rohkem hinnanguid, lugu ise jäi peajoontes samaks. Usutavasti, kui Betti Alverile oleks antud rohkem aega, ei oleks need mustandmaterjalid meieni jõudnud, ja puhtandpäevikust kooruv lugu on just selline, nagu ta seda maailmale tahtis näidata. Otsustasin uued üksikasjad jätta oma jutustusse põimimata. Mida olulist lisakski täpsustus, et Talvi Laeva tõlkeüritus tundus Betti Alverile algul ebamäärane ja just seetõttu ei rutanud ta vastama, või et sõnumit võimaliku Nobeli auhinna kohta ta esimeses elevuses mõne inimesega jagas, hiljem aga oma avameelsust kahetsedes palus teadet mitte levitada, mõne teise usaldusaluse ees aga vaikis sellest sootuks? Küll aga tundub oluline ära nimetada ehtalverlik kokkuvõte kogu loost: „13. okt. õ. raadios teade. N. pr. 1988 Egiptus, jama niisiis 1. nov.-st 1987 kuni 13. okt.-ni 1988” (KM EKLA, f 315, m 91: 3, l 10).

Selline dramaatiline lugu ja sellest sündinud suure inimese ja suure luuletaja viimne läkitus: mitte millegi ega kellegi orjaks saada, uskuda hingeimesid, tahta võimatut, hoolimata kõigest, hoolimata sellest, et oled kogu elu olnud persona non grata! Siin kordub see, mis on olemas Betti Alveri loominguski, ent avatumalt, vahetumalt, valulisemalt, saab selgemaks hingevõlg, saavad selgemaks elu valupunktid, loojakreedo.

Betti Alveri selgitusi oma elu ja loomingu kohta ei ole palju. Siiski toovad need teateid pea kõigi tema loometöö aastakümnete kohta. ${ }^{10}$ Siinsed haruldased märkmed Betti Alveri elu lõpupäevilt on sündinud viimase luuletuskogu, „kildhaaval valminud eluromaani” (Muru 2003: 235) järelhoovuses, kujutavad endast tagasivaadet elatud elule ning omalaadse vaimse testamendina väärivad tervikuna avaldamist. ${ }^{11}$

Publikatsiooni valmimist on toetanud Eesti Haridus- ja Teadusministeeriumi uurimisprojekt IUT 22-2 „Kirjanduse formaalsed ja informaalsed võrgustikud kultuuriloo allikate põhjal".

KRISTI METSTE

${ }^{10}$ Intervjuud ja muudki isiklikku on avaldatud raamatus „Betti Alver. Usutlused, kirjad, päevikukatked, mälestused" (vt nt Lillemets, Metste 2007: 57-72, 93-97, 124-130, 206-208, 234-237, 344-348, 370-373, 484-488).

${ }^{11}$ Mõni katkend neist on avaldatud luuletuskogu „Omajuur” saatesõnas (Metste 2017: $318-320)$. 


\section{Arhiiviallikad}

Eesti Kirjandusmuuseum, Eesti Kultuurilooline Arhiiv, f 315. Betti Alveri - Mart Lepiku kogu:

KM EKLA, f 315, m 2: 1. Betti Alveri kiri Talvi Laevale 26. II 1988.

KM EKLA, f 315, m 5: 2. Betti Alver, Kirjade ärakirju, kontsepte, märkmeid.

KM EKLA, f 315, m 6: 1. Betti Alver, Kirjade ärakirju, kontsepte, märkmeid.

KM EKLA, f 315, m 11: 7. Anne-Malle Halliku kirjad Betti Alverile 22. III 1980 - 19. II 1988.

KM EKLA, f 315, m 17: 7. Talvi Laeva kirjad Betti Alverile 8. IX 1987 - 17. II 1988.

KM EKLA, f 315, m 20: 12. Kathryn Metsa kirjad Betti Alverile 2. X 1969 21. XII 1988.

KM EKLA, f 315, m 31: 5. Mardi Valgemäe kirjad Betti Alverile 18. VI 1988 5. IX 1988.

KM EKLA, f 315, m 78. Betti Alver, Üle aegade Assamalla. Koostamise materjal.

KM EKLA, f 315, m 87: 1. Betti Alver, Päevik. 1977-1988.

KM EKLA, f 315, m 91: 3. Betti Alver, Päevik. 1988-1989.

KM EKLA, f 315, m 151: 15. Gabriella Mirollo, Talvi Laev, tõlked Betti Alveri luulest.

\section{Kirjandus}

Aleksiu s, Malle 1989. Betti Alveri luulet inglise keeles. - Sirp ja Vasar 2. VI, lk 13.

Iv a sk, Ivar 1988. Minu algpunkt on Rõngu. - Sirp ja Vasar 14. X, lk 4.

Ka s e m a a, Kalle 1988. Nagīb Maḥfūzist. - Looming, nr 12, lk 1715-1717.

Ki in, Sirje 2012. Eestlane algatas ameeriklaste Nobeli. - Eesti Ekspress 20. IX, $\mathrm{nr} 38, \mathrm{lk} 22$.

Lillemets, Enn, Metste, Kristi 2007. Betti Alver. Usutlused, kirjad, päevikukatked, mälestused. Lisandusi tundmiseks. Tallinn: Tänapäev.

Mets te, Kristi 2006. Betti Alveri päevikuid lehitsedes. - Tuna, nr 3, lk 118-141.

Metste, Kristi 2017. See omajuur või mis ta oli .... - Betti Alver, Omajuur. Koostanud K. Metste. Tallinn: Tänapäev, lk 315-321.

M u r u, Karl 2003. Betti Alver. Elu ja loomingu lugu. Tartu: Ilmamaa.

Põld m ä e, Asta 2014. Ja valguse armulise. Kirjatöid aastaist 1975-2013. Tallinn: Eesti Keele Sihtasutus.

Süvalep, Ele 2005. Saateks. - Betti Alver, Koguja. Suur luuleraamat. Tartu: Ilmamaa, lk 529-532.

The Nobel Prize 1988 = The Nobel Prize in Literature 1988 Naguib Mahfouz. Press

Release. October 13, 1988; http://www.nobelprize.org/nobel_prizes/literature/ laureates/1988/press.html (25. I 2017).

Viirlai d, Arved, Parming, Tõnu 1989. Preface. - Betti Alver, Selected Poems.

Toronto: Estonian Centre, International P.E.N. 


\section{Betti Alveri Nobeli-kõne kavand}

Luule. 1988 aug. $^{1}$

[1. osa]

Päris algus

teatud oludes inimese kõige kõrgem tiitel: persona non grata

Etteheited saatusele, loodusele, elule, iseendale

kuid

midagi suuremat kõige taga

mitte ühtki gruppi, mitte ühtki parteid teenida, vaid seda, mis on omane igale inimhingele maailmas

Isegi loodusele olid mul omad pretensioonid

Oleksin tahtnud talle saata kirja täis etteheiteid ja

Mind kohutas, et kõik (raske ja kurb) nii kergesti unus, - nagu nüüdki, kui raadios räägitakse kohutavatest mõrvadest ja inimeste kannatustest - rääkija sama hingetõmbega ütleb:

saadame nüüd kerget, lõbusat muusikat (2. okt.)

Päris algus (8. sept)

Kõrgus, kuhu mind on tõstetud

kui see kuidagi oleks kiireks mu väikesele ohustatud rahvale

8. sept.

„Või mis võitleja olin või olen mina siin ... (mistahes) tandril, kui kõige julmemalgi ajal oli (ja on) mul peaaegu võrdselt kahju nii julmuse ... ohvrist kui julmurist endast

õiglus, kohtumõistjad

siis teadsin, et ... et võim on ... rusikaõigus, et igal võimul on nn. õigluse nimel toimetavad kohtumõistjad ... ja timukad

Kuid maine kättemaks, võim, pole laulikute (asi), sest laulik ei loovutaks kogu maailma hüvede nimel ühtki lapsukest ega rauka, ühesõnaga mitte ühtegi elu

8. sept.

Mitte ühtki gruppi, mitte ühtki parteid teenida, vaid seda, mis on omane igale inimhingele kogu maailmas

Isegi loodusele olid mul oma pretensioonid - ma ei tahtnud olla ainult tema pime tööriist

Tugi ja telg iseendas

${ }^{1}$ Märkmed on avaldatud selles järjestuses, nagu ümbrikus on. Kaalumisel olnud kronoloogiline esitus oleks lõhkunud mõttelise struktuuri, mis neis tundub olevat. Edastatud on kogu tekst, mahatõmmatud tekstiosad on ka siin läbi kriipsutatud. Kirjutaja mõtete kulgu järgides on säilitatud teksti liigendus. Ruumi kokkuhoiu huvides ühte ritta asetatud tekstis on reapiir tähistatud kaldkriipsuga. Mõttepunktid ja ümarsulud, samuti joontega rõhutused tekstis pärinevad Betti Alverilt, nurksulgudes on toimetaja märkused. Kui on teisiti, siis on sellele kommentaaris osutatud. 
9. sept. 88

... ja räägin enda nimel, ainult enda nimel

Avalik kiri Loodusele, õieti kaebekiri Loodusele, miks ta on

kus ma oleksin Teda muidugi tänanud kõige võrratu eest meis ja me ümber ka meie mõistuse, vaimu ja hinge eest, luule eest, võib-olla ka me õnne, rõõmu ja mõningate kannatuste eest

kuid miks ta on loonud niipalju eeldusi meis kurjuse ja julmuse jaoks, niipalju tarkust ja kurikavalust enesehävitamiseni

Või pole süüdi Loodus, vaid siiski ainult meie ise, kes me ei oska meile antud eeldusi kasutada?

6./7. okt.

Ma ei tunne ennast tänini. Võin ainult aimata, miks ma nii või teisiti käitu(si)n. Ja ometi mingi stabiilsus.

[2. osa]

Tahta võimatut on meie saatus ${ }^{2}$

Sisse kodeeritud:

Põgenemine õnne eest, au, tiitlite, odava populaarsuse jne (Ida jne) eest mida õieti märkasin ja veidi taipasin alles palju-palju hiljem.

Persona non grata

1. okt. 88

Õnne ootus

kaunim kui kättesaadud õnn (unistus)

Põgenemine (vist alateadlik)

2. okt.

Kes mind on aidanud

Kõik sõnad on ilmaaegu

kui lugeja ise pole (luuletaja?)

1. okt. 88

„Kui saaks kord vähemalt keisri kemmergupesijaks!”

... et õnn mind ise taga ajaks

Tahtsin maksta kõige kõrgemat hinda

11. sept. 88

Juba (väga vara) lapsena õppisin ma (vähemalt oma südames) ütlema väga paljude asjade kohta: ei!

Imetlus, armastus ja protest

Ma ei tahtnud ega taha tänini olla kellegi, ka mitte looduse, pime tööriist

Juba väga vara ma ei usaldanud ega uskunud nn. (käibe)tõdesid, vaid ootasin ja eeldasin ikka midagi suuremat, kõrgemat - ühesõnaga midagi võimatut Ainult usk võimatusse on mind alati, ka kõige raskematel aegadel aidanud (11. sept.)

${ }^{2}$ Luuletuse „Vabaduse deemon” (1936) teine värss. 
10. sept.

Persona non grata

Persona gratissima ${ }^{3}$

Mul oli au olla persona non grata seisuses

Ikka see tunne: / Mida iial ei olnud, / võib ilmuda kohe ${ }^{4}$

Aus dem Verständnis für die Vielfalt der Wesensformen und aus der Achtung vor dem Anderssein möge dann die Erkenntnis erwachsen, dass hinter allen Eigen-Arten das Gemeinsame alles Menschlichen zu suchen ist. (Das Elefantenspiel [Aafrika muinasjutud] lõpus) ${ }^{5}$ (11. sept. 88)

1988 9. sept. (1)

Arusaamatu maailm.

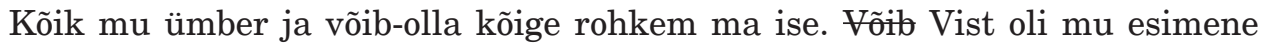
sõna nagu meil kõigil:

mis?

Aga kohe seejärel:

miks?

Mind hämmastas minus endas

1) miks jooksin rõõmu eest ära? (Ida tulek)

2) ikka tundsin end süüdlasena

3) ma ei uskunud (reaalsust), uskusin imet

8. sept. 88

Jäägu teistele alandlik jaatus

Tahta võimatut on meie saatus ${ }^{6}$

Ema

Väga, paraku väga vara hakkas mind piinama aimus kõige kallima kaotusest

Ema

$\overline{\overline{(k u n i n g l i k ~ t o ̃ l d ~})^{7}}$

$\underline{\text { Iteps }}$

$\underline{\text { Luule }}$

Keel

${ }^{3}$ Kõige meeldivam, kõige soovitum isik.

${ }^{4}$ Luuletuse „Elul on väikene hingemaa” (1986) lõpuvärsid.

${ }^{5}$ Siin Betti Alveri nurksulud. Tõlge: „Alles kõigi olemise vormide mitmekesisuse mõistmisest ja lugupidamisest teistsuguse vastu võiks kasvada äratundmine, et kõigele inimlikkusele ühist tuleb otsida kõigi eripärasuste tagant." Tsitaat pärineb toimetuse märkusest raamatusarja "Das Gesicht der Völker” kohta, kus ilmus ka viidatud „Elevandimäng” (Das Elefantenspiel. Mythen, Riesen- und Stammessagen. Volkserzählungen der Tindiga. Toim L. Kohl-Larsen. Eisenach, Kassel: Erich Röth-Verlag, 1956). Teos leidub Betti Alveri - Mart Lepiku memoriaalkogus Eesti Kirjandusmuuseumi Arhiivraamatukogus. Samast sarjast on kogus veel „Söhne des tötenden Vaters. Dämonen und Kopfjägergeschichten aus Neuguinea" (1957).

${ }^{6}$ Luuletuse „Vabaduse deemon” kaks esimest värssi.

${ }^{7}$ Vt luuletus „Sim-sala-bim” (1977). 
14. sept. (II)

Tahtsin teada, mis oli see, kus oli see Esimene impulss, mis kord kõik liikuma pani, millest kõik alguse sai.

Niipalju ma siiski taipasin, et seda (inimsõnaga) defineerida ei saa, et see oli valdkond, kuhu ühegi esialgu vist ükski teadus ei jõua, kuid et võib-olla kauges tulevikus väga kaugele jõudnud inimkond parem inimkond seda saladust riivab [?] ${ }^{8}$

Esimestest aimudest alates, esimestest (rõõm, ilu ...

saadik ütles mu lapsesüda ühtlasi (väga) paljudel puhkudel

$\underline{\underline{\underline{\mathrm{Ei}}}}$

14. sept. (III)

End hoida selle sõnastamatu jaoks, mitte viimseks, millegi või kellegi orjaks saada. Nii pagesin mõnegi rõõmu eest (Põgenemine Ida tulekul)

14. sept. (IV)

Poolpimedas vana kuuseheki all kükitades

ma ei saanud enesest õieti aru, kuid ma olin siiski rohkem õnnelik kui õnnetu. Mu käed, mu silmad, mu süda pidid valmis olema millegi veel suurema vastuvõtmiseks

14. sept.

Midagi Muud

Midagi Rohkemat

Suuremat

Kõrgemat

See oli ju tohutu palju, mida sai tunda, tunnetada, mõelda, võrrelda, millest unistada, kuid see bioloogiline, hingeline, vaimne aparatuur, mis me olime Looduselt kaasa saanud, tundus mulle vägagi puudulik ja ebapiisav. Aimuste ja igatsuste uksi avada suutis ainult Luule

19. sept. 88

Ma ei saanud kiita midagi, milles ma kindel ei olnud. Kõige kindlam olin ja olen ma inimese südametunnistuses ja tema unistustes tahta võimatut. 19. sept. 88

20. sept. 88

Mina pole kohtumõistja. Ka praegune (kohutav) maailm pole kohtumõistja. Ainult see (arusaamatu, sügav) hääl meie sisemuses, mida me nimetame südametunnistuseks, süümeks, mõistab (esialgu) kohut (esmajoones) meie enda üle. Ning alles siis, kui see kohtunik meis kõigis on saanud eluõiguse ja võimu meie kõigi üle, oleme kord ehk võimelised otsustama ka teiste üle ja langetama otsust. Seni aga oleme alles teel sinnapoole läbi kohutavate katsetuste, õppetundide ja eksamite. Et meil $\operatorname{selles}^{9}$ ka mõningat edu on olnud, tõendab kasvõi see, et meie maine juba vägagi kahjustatud kodu on esialgu veel alles,

${ }^{8}$ Raskesti loetav sõna.

${ }^{9}$ Parandatud: selles pro sellel teel. 
et ahastav, kahtlev, hingepõhjani haavatud, igatsev ${ }^{10}$ ja pooleldi pimestatud inimkond veel elab, et me usume kasvõi ainult hingeimesid ning et

tahta võimatut

on meie saatus $^{11}$

(Sellega ehk lõpetada)

üles märgitud 20. sept. 88

13. sept. 88 (1)

et olen vastutav millegi või kellegi ees, mis või kes on kõrgem kui keiser, kuningas, kindral või minister. ${ }^{12}$ Ning et selle võimu (väikene) esindus

oli mu enda südames:

seda võis aimata, tunnetada ainult Luule

(2) Ennast anda: mitte viimseni, mitte lõplikult millelegi muule või kellelegi teisele, vaid kõige puhul säilitada side sellega, millele ma ei osanud, ei oska ega tahagi mingit kindlat nime anda. Ning just See on mind aidanud siiamaani.

Kerge see muidugi pole olnud.

24. sept. 88

Mina, kes ma olen olnud sellest ajast peale, kui hakkasin luuletama, persona non grata

... aga teatud aegadel, teatud olukordades vist ei olegi inimesele kaunimat tiitlit kui persona non grata

Tähtis!

ning ma taipasin, et teatud oludes, teatud ajajärkudel pole inimesele kõrgemat tiitlit kui persona non grata.

8. okt. (a)

... nagu oleks keegi komponeerinud mu elu ja iseloomu põhimeloodia ja mul tuli seda siis üksikute taktide, harmooniate ja dissonantside haaval tegelikkuses teostada

10. okt. (b)

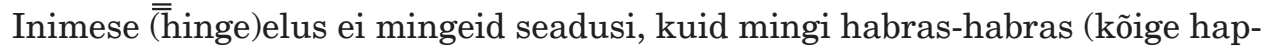
ram) vaevutabatav tsentrum (tuum), mis funktsioneerib - kui mitte teisiti, siis tagantjärgi (süümena, sisepiinana)

$\infty$

... ja keegi oleks nagu inimloomuse, inimsaatuse ette valmis planeerinud, sümptoomid lapsepõlves, mis alles palju, palju hiljem elus selguvad ja terviku juurde kuuluvad (tervik tohutu juhuslikkuse, ohtude ja muutuste maailmas)

\footnotetext{
${ }^{10}$ Parandus: ahastav, kahtlev, hingepõhjani haavatud, igatsev pro hingepõhjani haavatud ja igatsev.

${ }^{11}$ Kaks viimast rõhutust on tehtud jämeda lillakasroosa joonega (viltpliiats).

${ }^{12}$ Vrd „Kes oli su kaitsja / kord keisrite / aegu?

Kes hoiab / su lootust / kui lapsukest / praegu?

See on valu / mis läbib / me laulu / ja loomu.

See on tõde, / mis kõrgem / kui keiser / ja kroonu” („Kes oli su kaitsja?”, 1987)
} 
Ohutunne (11. sept. 88)

[3. osa] Luule / Võim / Laulikud [märksõnad ümbrispaberil]

(1)

1) Traagiline enesetunnetus

Ema (mitte alati)

2) Unustamine

kogesin väikese lapsena

3) $\underline{\text { Süütunne }}$

II

Abituse tunne.

kui kõik kaob

(lapsena: ema, isa) mu sõber, armsam, õpetaja, abikaasa, luuletaja (H. T.) hävitati

(2) Mõisted: ausus, halastus, (isegi elementaarne viisakus ja korrektsus), kaastunne - kõik $[\mathrm{X}]^{13}$ tembeldati valeks ja vaenulikuks

kui ei jäänud muud kui lein, valu, ahastus.

- mis oli see, mis ei lasknud kokku variseda, ennast alandada jne.

(3) Lubatagu, et ma ei hakka sellele abile, hoidjale, kaitsjale täpset nime ega definitsiooni otsima. Kuid see oli midagi, mis seotud vist nende nähtamatute allikatega, tänu millele inimkond

(4) pole lõplikult loomastunud (etc)

need ürgsed allikad, millest vist lähtub inimlikkus, luule

Mure, valu

Meie rahvalaul

Murelaulud

(5) Ja kuna ma juba väga vara aru sain, kui juhuslik, ebakindel, ebausaldatav on igasugune ametlik võim, ja ... kui vähe õiglust võib neilt loota, seda rohkem hakkasin usaldama neid jõudusid, neid hoopis tundmatuid ja

kellele ma ei osanud nime anda, kuid kelle päralt oli midagi suuremat ja vägevamat kui kõik maine võim, vägi ja au

(6) Ja nagu mulle tundus, pärines neilt kõik, mis inimkond oli loonud igavest ja head. Ma ei mõtelnud seejuures ei püramiididele, suurtele linnadele ega ... sest need kõik võisid varem-hiljem hävida - ja hävisidki - vaid ma mõtlesin neid jõude, mis ikka ja uuesti olid aegade jooksul elavana püsinud

- ka kõige raskematel pimedatel ajajärkudel

Ja sealt valdkonnast nagu ma ... aimasin ja tundsin, oli pärit ka luule

${ }^{13}$ Loetamatu sõna.

KEEL JA KIRJANDUS 8-9/2017 
$[7]^{14}$ Sõnade kartus on mulle ammugi omane

_"- inflatsioon

Mis on siirus?

Kõik - õilsad, haruldased, erandlikud. Kes on tunnistanud enda julmust? Ahnust? Alatust? Võib-olla ainult kõige suuremad mõnikord (Tolstoi, Dostojevski)

Enda piiratust, rumalust, pimedust (ei ole tunnistanud) vist mitte keegi. 22. aug. 88 esmasp. $^{15}$

sest raha kaudu sündinud reetmise [inflatsioon, BA] läbi tajusime, et ainult igavesed asjad meis olid tõesti püsivad. (St. Zweig, Die Welt v. Gestern, lk. $197)^{16}$

14. aug. $88 \underline{\text { Mure }}$

Murelaulikud Eestis

Rahvalaulud, Traagiline saatus

Kr. J. Pet. / Juh. Liiv / Marie Under / Marie Heiberg / Heiti Talvik / + G. Suits?

Ka rõõmust kirjutab murelaulik teisiti - sügavamalt

Võib-olla ainult murelaulik teab õieti, mis on rõõ [m] ja inimlik õnn

\section{4. aug. 88 Luule arusaadavusest}

Selles salapärases, mõistatuslikus maailmas, kus on hingel nii raske orienteeruda, kus on nii palju valet, ebausku, pean (mina vähemalt) luuletaja osaks ${ }^{17}$ kõnelda siiski siiralt oma tunnetest ja mõtetest

kasvõi selle riisikoga, et teda mõneti naiivseks ja sentimentaalseks peetakse. Pimedusse pole mõtet pimedust juurde tuua.

Lõpetada $^{18} 14$. aug.

Selles imepärases, nii paljude võimalustega salapärases elus siin imeilusas ${ }^{19}$, rikkas, julmas, heldes ja kohutavas maailmas

${ }^{14}$ Leht Alveri poolt nummerdamata. Lehe lõpus olev daatum „22. aug. 88, esmasp.” lubab oletada, et märkmed neil seitsmel lehel on kõik tehtud selsamal kuupäeval - paber on sama ja ka kirjutusvahend tundub olevat sama.

${ }^{15}$ Järgnevad fragmendid on teistsugustel paberilehtedel.

${ }^{16}$ Tsitaat pärineb Stefan Zweigi raamatust „Eilne maailm” („Die Welt von Gestern”), õieti selle tõlkest eesti keelde, mis leidub ka Betti Alveri - Mart Lepiku memoriaalkogus (teost saksa keeles seal ei ole). Nurksulgudes on Alver lisanud täpsustuse asja sisu selgituseks. Tsiteerigem selguse huvides Zweigi veidi pikemalt: „Sest just ootamatuse tõttu, et kunagi kõige stabiilsem asi, raha, minetas päev-päevalt väärtust, hindasid inimesed elu tõelisi väärtusi - tööd, armastust, sõprust, kunsti ja loodust - seda kõrgemalt, ja terve rahvas elas keset katastroofi intensiivsemalt ja pingsamalt kui iial. [---] Ja mis oli meile enne tähtis olnud, muutus veel tähtsamaks: iial ei armastanud me Austrias kunsti rohkem kui neil kaoseaegadel, sest raha kaudu sündinud reetmise läbi tajusime, et ainult igavesed asjad meis olid tõesti püsivad." (S. Zweig, Eilne maailm. Eurooplase mälestused. Tallinn: Eesti Raamat, 1988, lk 196-197.)

${ }^{17}$ Parandatud: osaks pro ülesandeks.

${ }^{18}$ Mitme alla tõmmatud joonega rõhutatud.

19 Parandatud: paljude võimalustega salapärases elus siin imeilusas pro paljude võimalustega elus siin imepärases. 
8. aug. 88

Luule / Oleks armetu ja koomiline, kui mina, ühe nii väikese rahva tundmatu ... suurele maailmale ja tema .... loojatele midagi suurt, uut luule kohta öelda. tuule algab sealt, kus algab inimese valu.

Aga lubatagu siiski, et ütlen sel puhul midagi, mis mulle oleks nagu selgunud kasvõi meie, eestlaste väga pikaajalisest luulekogemusest.

Luule algab sealt, kus elava inimhääle saab valu. ${ }^{20}$

1) Meie rahvalaulud. Millised sügavad Kuigi meil on väga ... rõõmulaule, mis loodud kõige raskemates elutingimustes, pean ma tundesügavuselt ..... krooniks ometi murelaulusid. Lubage mul tsiteerida eesti keeles: Mullu jõin murekarika (tekst!) ${ }^{21}$

2) Meie esimene ...... (haritud) .... laulik Kristian Jaak Peterson (180...-18...), kes suri noorukieas ....

3) Lydia Koidula

4) Juhan Liiv

5) Marie Under

Marie Heiberg

6) Heiti Talvik

Ah, ma teadsin juba noorelt

7) Käesolevalgi ajal on meil mitmeid ..... luuletajaid ..... P.-E. Rummo

[Kahel eraldi lehel:]

Mood on, mis tuleb ja paratamatult läheb, ometi ta lühike liblikalennuline saatus $^{22}$ võib lisada suurde, ääretusse luulekangasse (kui tervikusse) nii mõnegi elustava enneolematu ...-udeme

30. juuli 88 (laup.). Võib-olla oleksin ma kogu maailmale ja oma kodumaale veidi paremat ja kergemat saatust soovinud. Kuid mis puutub minusse isiklikult - siis enesele vaevalt küll. Ainult nende kogemuste kaudu, ${ }^{23}$ mis mulle osaks said, õppisin aegade jooksul ka iseennast veidi tundma. Ma ei ütleks, et mu isiklikud kogemused eriti julmad oleksid olnud. Kõik siin maailmas on ju suhteline. Julmaks võib mu kogemusi ainult nende kannatuste pärast nimetada, mis teistele mu kaasaegsetele osaks said. Ja kuna see vist on paraku üldinimlik ja veidi ebaeetilinegi - olid need mu elamused eriti rasked mulle

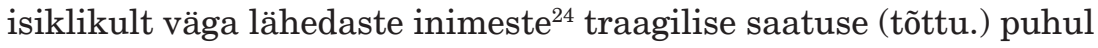

Karistus. Julmus. Iga kuritöö sisaldab endas ka karistuse momenti. Enda nimel andestaks maailmas kõik mõrvad. Ometi teiste nimel seda teha pole mul õigust.

${ }^{20}$ Vrd „Mu kaduv käsi / paberile / valujooni / veab ...” (luuletus „Kaduv käsi”, 1985).

${ }^{21}$ Betti Alver on värsse murelaulust kasutanud ühes uusaastatervituses: „Mullu jõin murekarika / tänavu jõin teise täie / kolmat kannu kallatakse ..." (KM EKLA, f 315, m 6: 1, l 19p). Need ei kattu ühegi lauluvariandiga, mis on eesti regilaulude andmebaasis (http:// www.folklore.ee/regilaul/) või eesti rahvalaulude antoloogias, mis leidub Betti Alveri - Mart Lepiku memoriaalkogus kirjandusmuuseumis (vrd Ü. Tedre (toim), Eesti rahvalaulud. Antoloogia. 2. köide, 1. vihik. Tallinn: Eesti Raamat, 1970, lk 334-335).

${ }^{22}$ Parandatud: saatus pro iga.

${ }^{23}$ Parandatud: kaudu pro hinnag[a].

${ }^{24}$ Parandatud: väga lähedaste inimeste pro väga lähedaste armsate inimeste. 